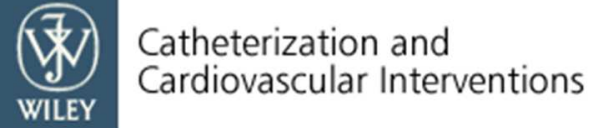

\title{
A feasibility study of trans-subclavian TAVI with the Lotus valve
}

\begin{tabular}{|r|l|}
\hline Journal: & Catheterization and Cardiovascular Interventions \\
\hline Manuscript ID & CCI-17-0782 \\
\hline Wiley - Manuscript type: & Original Studies \\
\hline Keywords: & $\begin{array}{l}\text { TVI - Transcatheter Valve Implantation, SHDI - Structural Heart Disease } \\
\text { Intervention, AVD - Aortic Valve Disease }\end{array}$ \\
\hline \multicolumn{2}{|l}{} \\
\hline
\end{tabular}

\section{SCHOLARONE ${ }^{m}$ \\ Manuscripts}


Full title: A feasibility study of trans-subclavian TAVI with the Lotus valve

Short title: Subclavian TAVI using the Lotus valve

Sagar N Doshi ${ }^{1}$, Sudhakar George ${ }^{1}$, Chun Shing Kwok ${ }^{2}$, Anthony Mechery ${ }^{1}$, Mamas Mamas ${ }^{2}$, Peter F Ludman $^{1}$, Jonathan N Townend ${ }^{1}$, Moninder Bhabra ${ }^{1}$

${ }^{1}$ Queen Elizabeth Hospital, Birmingham

${ }^{2}$ Royal Stoke University Hospital, Stoke

Address for correspondence:

Dr Sagar Doshi

Department of Cardiology

Queen Elizabeth Hospital

Birmingham

United Kingdom

Email:sagar.doshi@uhb.nhs.uk

Indexing words: Aortic valve disease, transcatheter valve intervention, structural heart disease intervention

Total word count: 3643,4360 with tables 
Abstract

Objectives

To assess the feasibility of subclavian transcatheter aortic valve implantation (TAVI) using the Lotus valve.

\section{Background}

TAVI is used to treat patients with severe aortic stenosis, with trans-femoral (TF) access being the safest and most widely used route. In the significant minority of patients unsuitable for this, there are reports that the subclavian artery may be safest alternative access route. The Lotus device is a fully retrievable 2 nd generation transcatheter heart valve which is licensed for femoral and transaortic access. There are limited data on the suitability of this valve for subclavian access.

\section{Methods}

We assessed the feasibility of trans-subclavian TAVI with the Lotus valve in patients unsuitable for TF TAVI. Between January and October 2016, we identified 10 patients who underwent transsubclavian TAVI with the Lotus valve. This cohort was compared with 347 (85\%) patients who underwent trans-femoral TAVI, 45 (11\%) patients who underwent and trans-apical or direct-aortic TAVI and the total group of 16 (4\%) patients who underwent subclavian TAVI.

Results 10 patients aged 75 years (69-83) underwent attempted TAVI with the Lotus via subclavian access. Procedural success was $100 \%$. In-hospital and 30 -day mortality was zero. There were no nerological eventss, no vascular complications and no myocardial infarctions. 4 of 10 patients required a pacemaker post TAVI. No patient was left with moderate or greater aortic regurgitation. Median length of stay was 3 days post-procedure.

\section{Conclusions}

TAVI with the Lotus valve is feasible via the subclavian artery and appears safe with excellent outcomes in our patients.. 
TAVI is most commonly performed via the femoral artery ${ }^{8,9}$. Trans-femoral access is associated with lower rates of mortality when compared to other routes ${ }^{10,11}$ which has led most operators to adopt a "trans-femoral first" access strategy. TAVI requires relatively large sheaths (minimum 14$\mathrm{Fr}$ ) and delivery catheters and the transfemoral approach may not be feasible in patients with unsuitable vasculature. The trans-aortic and trans-apical are the most commonly used alternative access routes but have disadvantages including the greater invasiveness of a surgical thoracotomy ${ }^{12}$. The trans-subclavian approach to TAVI was initially described using the CoreValve (Medtronic, USA) ${ }^{13}$ and subsequently using the Sapien valve (Edwards, USA $)^{14}$. Evidence is emerging that the transsubclavian route is safe ${ }^{15}$. Observational data have demonstrated that survival following subclavian access is not significantly different from survival following TF access while survival following transaortic/trans-apical access was significantly lower than trans-femoral and subclavian access ${ }^{16,17}$.

The Lotus System (Boston Scientific, USA) is a $2^{\text {nd }}$ generation trans catheter heart valve approved for use in Europe in October 2013 and currently under evaluation in the USA. It is fully repositionable and retrievable, designed to facilitate precise delivery ${ }^{18}$ and has excellent results at 1 year, particularly in minimising para-valvular aortic regurgitation ${ }^{19}$. This is particularly important as moderate or greater para-valvular regurgitation is associated with increased mortality following $\mathrm{TAVI}^{5,20}$. Initially implanted via the femoral route, the valve is now licensed for trans-aortic access also. The Lotus valve is currently not licensed in Europe for trans-subclavian access although there is is one report of the Lotus valve being delivered successfully via the subclavian artery ${ }^{21}$.

\section{Methods}

Between December 2008 and October 2016, our institution (Queen Elizabeth Hospital Birmingham, UK) performed 408 TAVI procedures. Demographic, procedural and outcome data were entered prospectively to the National Institute for Cardiovascular Outcomes Research database. The preferred access site was the femoral artery and this was used in 347 (85\%) patients. Forty-six (11\%) patients underwent trans-aortic/tran-apical access and $16(4 \%)$ underwent trans-subclavian access of whom 10 underwent attempted TAVI with the Lotus Valve (Boston Scientific, USA). Valve types implanted were Edwards Sapien (Irvine, CA, USA), 24 (5.8\%); Edwards Sapien XT, 131 (32.1\%); Edwards Sapien 3, 213 (52.2\%), Lotus valve, 33 (8\%); CoreValve (Medtronic, USA) 3 (0.7\%); Evolute R (Medtronic, USA) 3 (0.7\%). Between January and October 2016, 10 patients who were unsuitable for transfemoral TAVI underwent the procedure using the Lotus valve via the left subclavian artery. 
All patients underwent a gated cardiac muti detector CT (MDCT)and helical MDCT of the aorta and ilio-femoral vessels. All patients were assessed by the Heart Team as being unsuitable for open heart surgery.

\section{Lotus Valve}

The Lotus valve consists a woven, nitinol wire, self-expanding frame to which is mounted a bovine pericardial aortic valve and is designed for catheter based introduction. The valve is expanded via controlled mechanical expansion. Rapid pacing is not required during valve deployment; the valve functions early in the deployment cycle and can be repositioned or fully retrieved at any point before uncoupling and valve release. An outer adaptive seal is designed to minimize paravalular leak. Currently 3 valve sizes are available; 23, 25 and $27 \mathrm{~mm}$ and are suitable for an aortic valve annulus in the range $\geq 19 \mathrm{~mm}$ and $\leq 27 \mathrm{~mm}$. The $23 \mathrm{~mm}$ valve is introduced through an $18 \mathrm{~F}$ sheath and the 25 and $27 \mathrm{~mm}$ devices through a $20 \mathrm{~F}$ sheath. The $18 \mathrm{~F}$ sheath requires a vessel lumen of $\geq 6 \mathrm{~mm}$ and the $20 \mathrm{~F}$ requires a vessel lumen of $\geq 6.5 \mathrm{~mm}$.

\section{Patient selection}

10 patients unsuitable for trans-femoral access with any device used at our institution were selected for Lotus implantation if their left subclavian artery was of suitable calibre for Lotus sheath introduction, if there was absence of concentric calcification and if annular area assessed by CT was within the recommended range for the Lotus device (currently $\geq 314 \mathrm{~mm}^{2}$ to $\leq 572 \mathrm{~mm}^{2}$ ). Assessment was made from the screening MDCT undertaken in all patients to assess access route.

\section{Subclavian access}

All procedures were performed under general anaesthesia with TOE monitoring. The left subclavian artery was exposed surgically and a suitable access area was identified by inspection and palpation. Using a Seldinger technique the subclavian artery was punctured within a purse string suture and a $5 \mathrm{~F} 11 \mathrm{~cm}$ sheath was introduced. Over a soft J-tipped $0.035^{\prime \prime}$ wire a $5 \mathrm{~F} \mathrm{Judkins} \mathrm{right} \mathrm{catheter} \mathrm{was}$ positioned in the ascending aorta and the soft $0.035^{\prime \prime}$ wire exchanged for a $180 \mathrm{~cm}$ Super Stiff $0.035^{\prime \prime}$ Amplatz wire. Over the stiff wire the 20F Lotus sheath was introduced with the distal tip placed in the ascending aorta under fluoroscopic guidance. The aortic valve was crossed and a 0.035 " small or extra small Safari Wire (Boston Scientific, USA) was placed in the left ventricle. Pre-dilatation was not performed in any patient. The Lotus valve was then introduced through the Lotus sheath with the catheter in an ' $\mathrm{S}$ ' configuration and implanted with standard technique.

\section{Statistical methods}

The populations were described using median and interquartile range for continuous variables and percentage for categorical variables. Statistical analysis was performed using STATA (College Station, USA).

The study complies with the Declaration of Helsinki. The data were collected as part of a mandatory UK national cardiac audit and all patient identifiable fields were removed before analysis. The study complies with section 251 of the National Health Service Act 2006. Ethical approval was not required under research governance arrangements for analyses. 
Results

Baseline Demographics

Baseline demographics are shown in table I.

Patients who received transaortic/transapical TAVI had significantly higher Logistic Euroscore than the patients undergoing transfemoral TAVI (19 vs 14; p0.001). Logistic Euroscore was also numerically higher in the entire subclavian cohort compared with the transfemoral group, although this did not meet significance ( $22 \mathrm{vs} 14 ; \mathrm{p}=0.07$ ). The transaortic/transapical and entire subclavian group more frequently had peripheral vascular disease than the transfemoral cohort $(p<0.001)$.

The 10 patients who underwent trans-subclavian TAVI were aged 75 years (69-83) with $60 \%$ being male. Compared with the trans-femoral group the cohort undergoing trans-subclavian TAVI with Lotus had more frequently undergone open heart surgery, had a greater frequency of peripheral vascular disease, diabetes and a higher BMI. Characteristics of the Lotus subclavian group were similar to the cohort who received trans-aortic or trans-apical TAVI.

\section{Procedural characteristics}

The majority of femoral TAVI cases were carried out under local anaesthetic whilst all transsubclavian cases and all transaortic/transapical cases were performed under general anaesthetic. The rates of post -dilatation and choice of TAVI valve used can also be seen in table II.

\section{Outcomes}

Procedural outcomes are shown in table III.

Procedural success, defined as a successful attempt to implant a valve to the annulus, was high in the whole cohort with the valve implanted successfully in $99 \%$ of patients. In the entire population rates of major complications including in-hospital death (4.7\%), 30-day mortality (4.4\%), periprocedural $\mathrm{MI}(1.6 \%)$, peri-procedural stroke $(0.8 \%)$ and major access site complications $(2.3 \%)$ were low. The requirement for permanent pacing post TAVI and before discharge was $7.4 \%$.

All 10 patients undergoing trans-subclavian with Lotus required a $20 \mathrm{~F}$ sheath for a 25 or $27 \mathrm{~mm}$ valve. The sheath was successfully passed into the ascending aorta in 9 patients. In one patient, the tip of the sheath would not pass an area of calcification in the proximal subclavian artery, however, the delivery sheath, being of narrower diameter, successfully traversed the obstruction and the valve was deployed uneventfully. There was no haemodynamic instability or ECG evidence of ischaemia in any of the 4 patients with patent IMAs during the procedure following introduction of the sheath. Procedural success was achieved in all patients. Passage of the Lotus THV to the native aortic valve was uncomplicated in all patients. Due to the short distance from the access site to the native aortic valve and as the catheter was delivered in an ' $S$ ' configuration, the catheter naturally self-oriented and proved extremely easy to deliver. Post implant valve gradients were low and no patient required valvuloplasty post valve deployment. 4 of the 10 patients $(40 \%)$ required a pacemaker due to heart block at the end of the procedure. None of these patients had pre-existing conduction abnormalities such as right bundle branch block or first degree heart block on electrocardiogram. There were no vascular complications or access site related problems in any of the 10 patients. 2 patients with morbid obesity (BMI 40 and 47) were extubated on ITU. The remaining 8 patients were extubated 
immediately after TAVI in the catheter laboratory and then transferred directly to the coronary care unit. Patients were able to mobilise quickly after the procedure. The median length of stay was significantly lower in the entire subclavian group compared with the transapical/transaortic group ( 3 days vs 7 days, $p<0.001)$. Significantly more patients in the transaortic/transapical group (28\%) required blood transfusions than the transfemoral group (9\%) or subclavian group (6\%). No statistical difference was seen in the rate of blood transfusion between the subclavian and transfemoral groups. The transaortic/transapical group more frequently required dialysis than either the subclavian or transfemoral groups.

Peak CRP and peak total CPK were both significantly higher in the transapical/transaortic cohort compared with the entire subclavian group. $67 \%$ of patients in the transapical/transaortic group required a chest drain compared with $0 \%$ in the subclavian group.

\section{Discussion}

Our study demonstrates that TAVI via the subclavian artery using the Lotus valve is feasible and safe with similar outcomes to those receiving transfemoral TAVI. The valve was deployed successfully in all 10 patients with no major complications (death, peri-procedural stroke or $\mathrm{MI}$, access site problems) until discharge. This is the largest reported series of patients to have undergone TAVI via the subclavian artery with the Lotus valve. It should be noted that in this cohort of patients there was a relatively high requirement for permanent pacing either during or immediately following the procedure ( $40 \%$ of patients). A high rate of requirement for permanent pacing of $28.6 \%$ was also originally described with use of the valve from the femoral artery ${ }^{22}$. None of the patients in our cohort of patients had moderate or severe paravalvular regurgitation.

Patients who underwent subclavian TAVI had fewer deaths and TIA/stroke than the cohort of patients who underwent transapical or direct aortic TAVI. Although both groups of patients required general anaesthesia and surgical cut down, transapical and direct aortic access are more invasive due to the need for a sternotomy or thoracotomy, and the requirement to open the pericardium. Transaortic/transapical access was associated with a higher need for blood transfusion than subclavian access and these patients also usually required a chest drain immediately following the procedure. The greater invasiveness of transaortic/transapical access was reflected in the markedly higher peak CRP compared with the subclavian cohort. CRP is a marker of the systemic inflammatory response ${ }^{23}$ and a high CRP post cardiothoracic surgery is associated with a higher risk of major cardiovascular adverse events ${ }^{24}$.

Further evidence of the more invasive nature of transapical/transaortic access was the observation that these patients experienced longer lengths of stay both in the intensive care unit and in hospital compared to patients who underwent subclavian TAVI. This has important beneficial implications of subclavian access for both for patients, who enjoy a reduced hospital stay, and healthcare providers by reducing overall costs. 


\section{Study limitations}

The main limitation of our study is that the cohort of patients who underwent subclavian TAVI via the subclavian artery was relatively small at 16 patients. A further limitation is that this is not a randomised study. Finally, we do not yet have long term follow up data on the group of patients who had subclavian TAVI using Lotus.

\section{Conclusion}

In our cohort of patients, TAVI with the lotus valve using a trans-subclavian approach was safe and had outcomes comparable to TAVI via the transfemoral route. Patients who underwent transsubclavian TAVI had significantly fewer complications and required a shorter hospital stay than those undergoing transaortic or direct apical procedures. Our data are consistent with the growing body of evidence that suggests subclavian access is safer and less invasive than transaortic/transapical access and may be the preferred alternative access. 


\section{References}

1. lung B, Baron G, Butchart EG, Delahaye F, Gohlke-Bärwolf C, Levang OW, Tornos P, Vanoverschelde J-L, Vermeer $F$, Boersma $E$, Ravaud $P$, Vahanian A. A prospective survey of patients with valvular heart disease in Europe: The Euro Heart Survey on Valvular Heart Disease. Eur Heart J. 2003;24:1231-1243.

2. Nkomo VT, Gardin JM, Skelton TN, Gottdiener JS, Scott CG, Enriquez-Sarano M. Burden of valvular heart diseases: a population-based study. Lancet Lond Engl. 2006;368:1005-1011.

3. Leon MB, Smith CR, Mack M, Miller DC, Moses JW, Svensson LG, Tuzcu EM, Webb JG, Fontana GP, Makkar RR, Brown DL, Block PC, Guyton RA, Pichard AD, Bavaria JE, Herrmann HC, Douglas PS, Petersen JL, Akin JJ, Anderson WN, Wang D, Pocock S, PARTNER Trial Investigators. Transcatheter aortic-valve implantation for aortic stenosis in patients who cannot undergo surgery. N Engl J Med. 2010;363:1597-1607.

4. Smith CR, Leon MB, Mack MJ, Miller DC, Moses JW, Svensson LG, Tuzcu EM, Webb JG, Fontana GP, Makkar RR, Williams M, Dewey T, Kapadia S, Babaliaros V, Thourani VH, Corso P, Pichard AD, Bavaria JE, Herrmann HC, Akin JJ, Anderson WN, Wang D, Pocock SJ, PARTNER Trial Investigators. Transcatheter versus surgical aortic-valve replacement in high-risk patients. N Engl J Med. 2011;364:2187-2198.

5. Leon MB, Smith CR, Mack MJ, Makkar RR, Svensson LG, Kodali SK, Thourani VH, Tuzcu EM, Miller DC, Herrmann HC, Doshi D, Cohen DJ, Pichard AD, Kapadia S, Dewey T, Babaliaros V, Szeto WY, Williams MR, Kereiakes D, Zajarias A, Greason KL, Whisenant BK, Hodson RW, Moses JW, Trento A, Brown DL, Fearon WF, Pibarot P, Hahn RT, Jaber WA, Anderson WN, Alu MC, Webb JG. Transcatheter or Surgical Aortic-Valve Replacement in Intermediate-Risk Patients. N Engl J Med. 2016;374:1609-1620.

6. Vahanian A, Alfieri O, Andreotti F, Antunes MJ, Barón-Esquivias G, Baumgartner $H$, Borger MA, Carrel TP, De Bonis M, Evangelista A, Falk V, Lung B, Lancellotti P, Pierard L, Price S, Schäfers H-J, Schuler G, Stepinska J, Swedberg K, Takkenberg J, Von Oppell UO, Windecker S, Zamorano JL, Zembala M, ESC Committee for Practice Guidelines (CPG), Joint Task Force on the Management of Valvular Heart Disease of the European Society of Cardiology (ESC), European Association for Cardio-Thoracic Surgery (EACTS). Guidelines on the management of valvular heart disease (version 2012): the Joint Task Force on the Management of Valvular Heart Disease of the European Society of Cardiology (ESC) and the European Association for Cardio-Thoracic Surgery (EACTS). Eur J Cardio-Thorac Surg Off J Eur Assoc Cardio-Thorac Surg. 2012;42:S1-44.

7. Nishimura RA, Otto CM, Bonow RO, Carabello BA, Erwin I John P, Guyton RA, O'Gara PT, Ruiz CE, Skubas NJ, Sorajja P, Sundt I Thoralf M, Thomas JD. 2014 AHA/ACC Guideline for the Management of Patients With Valvular Heart DiseaseA Report of the American College of Cardiology/American Heart Association Task Force on Practice Guidelines. J Am Coll Cardiol. 2014;63:e57-e185.

8. Moat NE, Ludman $P$, de Belder MA, Bridgewater $B$, Cunningham AD, Young $C P$, Thomas $M$, Kovac J, Spyt T, MacCarthy PA, Wendler O, Hildick-Smith D, Davies SW, Trivedi U, Blackman DJ, Levy RD, Brecker SJD, Baumbach A, Daniel T, Gray H, Mullen MJ. Long-Term Outcomes After Transcatheter Aortic Valve Implantation in High-Risk Patients With Severe Aortic Stenosis: The U.K. TAVI (United Kingdom Transcatheter Aortic Valve Implantation) Registry. J Am Coll Cardiol. 2011;58:2130-2138. 
9. Mack MJ, Brennan JM, Brindis R, Carroll J, Edwards F, Grover F, Shahian D, Tuzcu EM, Peterson ED, Rumsfeld JS, Hewitt K, Shewan C, Michaels J, Christensen B, Christian A, O'Brien S, Holmes D, STS/ACC TVT Registry. Outcomes following transcatheter aortic valve replacement in the United States. JAMA. 2013;310:2069-2077.

10. Khatri PJ, Webb JG, Rodés-Cabau J, Fremes SE, Ruel M, Lau K, Guo H, Wijeysundera HC, Ko DT. Adverse effects associated with transcatheter aortic valve implantation: a meta-analysis of contemporary studies. Ann Intern Med. 2013;158:35-46.

11. Blackstone EH, Suri RM, Rajeswaran J, Babaliaros V, Douglas PS, Fearon WF, Miller DC, Hahn RT, Kapadia SR, Kirtane AJ, Kodali SK, Mack M, Szeto WY, Thourani VH, Tuzcu EM, Williams MR, Akin JJ, Leon MB, Svensson LG. Propensity-Matched Comparisons of Clinical Outcomes after Transapical or Transfemoral TAVR: A PARTNER-I Trial Substudy. Circulation. 2015;CIRCULATIONAHA.114.012525.

12. Walther T, Simon P, Dewey T, Wimmer-Greinecker G, Falk V, Kasimir MT, Doss M, Borger MA, Schuler G, Glogar D, Fehske W, Wolner E, Mohr FW, Mack M. Transapical minimally invasive aortic valve implantation: multicenter experience. Circulation. 2007;116:1240-245.

13. Fraccaro C, Napodano M, Tarantini G, Gasparetto V, Gerosa G, Bianco R, Bonato R, Pittarello D, Isabella $G$, Iliceto $S$, Ramondo A. Expanding the eligibility for transcatheter aortic valve implantation the trans-subclavian retrograde approach using: the III generation CoreValve revalving system. JACC Cardiovasc Interv. 2009;2:828-833.

14. Marcheix B, Grunenwald E, Carrie D, Dumonteil N. Implantation of a Sapien XT aortic bioprosthesis with the NovaFlex catheter through a subclavian access. J Thorac Cardiovasc Surg. 2012;143:753-755.

15. Petronio AS, De Carlo M, Bedogni F, Marzocchi A, Klugmann S, Maisano F, Ramondo A, Ussia GP, Ettori F, Poli A, Brambilla N, Saia F, De Marco F, Colombo A. Safety and efficacy of the subclavian approach for transcatheter aortic valve implantation with the CoreValve revalving system. Circ Cardiovasc Interv. 2010;3:359-366.

16. Blackman DJ, Baxter PD, Gale CP, Moat NE, Maccarthy PA, Hildick-Smith D, Trivedi U, Cunningham D, DE Belder MA, Ludman PF, National Institute for Cardiovascular Outcomes Research (NICOR). Do outcomes from transcatheter aortic valve implantation vary according to access route and valve type? The UK TAVI Registry. J Intervent Cardiol. 2014;27:86-95.

17. Fröhlich GM, Baxter PD, Malkin CJ, Scott DJA, Moat NE, Hildick-Smith D, Cunningham D, MacCarthy PA, Trivedi U, de Belder MA, Ludman PF, Blackman DJ, National Institute for Cardiovascular Outcomes Research. Comparative survival after transapical, direct aortic, and subclavian transcatheter aortic valve implantation (data from the UK TAVI registry). Am J Cardiol. 2015;116:1555-1559.

18. Meredith IT, Hood KL, Haratani N, Allocco DJ, Dawkins KD. Boston Scientific Lotus valve. Eurolntervention J Eur Collab Work Group Interv Cardiol Eur Soc Cardiol. 2012;8 Suppl Q:Q70-74.

19. Meredith IT, Walters DL, Dumonteil N, Worthley SG, Tchétché D, Manoharan G, Blackman DJ, Rioufol G, Hildick-Smith D, Whitbourn RJ, Lefèvre T, Lange R, Müller R, Redwood S, Feldman TE, Allocco DJ, Dawkins KD. 1-Year Outcomes With the Fully Repositionable and Retrievable Lotus Transcatheter Aortic Replacement Valve in 120 High-Risk Surgical Patients With Severe Aortic StenosisResults of the REPRISE II Study. JACC Cardiovasc Interv. 2016;9:376-384. 
20. Sinning J-M, Hammerstingl C, Vasa-Nicotera M, Adenauer V, Lema Cachiguango SJ, Scheer A-C, Hausen S, Sedaghat A, Ghanem A, Müller C, Grube E, Nickenig G, Werner N. Aortic regurgitation index defines severity of peri-prosthetic regurgitation and predicts outcome in patients after transcatheter aortic valve implantation. J Am Coll Cardiol. 2012;59:1134-1141.

21. Baştuğ S, Aslan AN, Sarı C, Süygün H, Bozkurt E. First trans-subclavian transcatheter aortic valve replacement using Lotus valve system. Turk Kardiyol Dernegi Arsivi Turk Kardiyol Derneginin Yayin Organidir. 2016;44:507-510.

22. Meredith Am IT, Walters DL, Dumonteil N, Worthley SG, Tchétché $D$, Manoharan G, Blackman DJ, Rioufol G, Hildick-Smith D, Whitbourn RJ, Lefèvre T, Lange R, Müller R, Redwood S, Allocco DJ, Dawkins KD. Transcatheter aortic valve replacement for severe symptomatic aortic stenosis using a repositionable valve system: 30-day primary endpoint results from the REPRISE II study. $J$ Am Coll Cardiol. 2014;64:1339-1348.

23. Castelli GP, Pognani C, Meisner M, Stuani A, Bellomi D, Sgarbi L. Procalcitonin and C-reactive protein during systemic inflammatory response syndrome, sepsis and organ dysfunction. Crit Care Lond Engl. 2004;8:R234-242.

24. Min JJ, Nam K, Kim TK, Kim HJ, Seo JH, Hwang HY, Kim KB, Murkin JM, Hong DM, Jeon Y. Relationship between early postoperative $\mathrm{C}$-reactive protein elevation and long-term postoperative major adverse cardiovascular and cerebral events in patients undergoing offpump coronary artery bypass graft surgery: a retrospective study. Br J Anaesth. 2014;113:391401. 
Table I - Baseline demographics of patients undergoing TAVI

\begin{tabular}{|c|c|c|c|c|c|c|c|}
\hline Variable & $\begin{array}{l}\text { Subclavian (all) } \\
(\mathrm{n}=16)\end{array}$ & $\begin{array}{l}\text { Subclavian } \\
\text { (Lotus)(n=10) }\end{array}$ & $\begin{array}{l}\text { Transapical and } \\
\text { direct aortic } \\
(n=45)\end{array}$ & $\begin{array}{l}\text { Femoral } \\
(n=347)\end{array}$ & $\begin{array}{l}\text { P value femoral } \\
\text { vs transaortic/ } \\
\text { transapical* }\end{array}$ & $\begin{array}{l}\text { P value femoral } \\
\text { vs subclavian* }\end{array}$ & $\begin{array}{l}\text { P value } \\
\text { subclavian vs } \\
\text { transaortic/ } \\
\text { transapical* }\end{array}$ \\
\hline Age, years & $78[72-84]$ & $75[69-83]$ & $81[75-85]$ & $83[78-86]$ & 0.38 & 0.20 & 0.83 \\
\hline Male sex & $12(75 \%)$ & $6(60 \%)$ & $24(53 \%)$ & $190(55 \%)$ & 0.86 & 0.11 & 0.13 \\
\hline Logistic Euroscore & $19[15-24]$ & $22[17-28]$ & $21[15-31]$ & $14[10-24]$ & 0.001 & 0.07 & 0.77 \\
\hline BMI & $\begin{array}{l}29.0 \text { [26.4- } \\
34.6]\end{array}$ & $30.9[26.8-36.2]$ & $26.7[23.5-29.4]$ & $\begin{array}{l}26.7 \text { [24.1- } \\
30.6]\end{array}$ & 1.00 & 0.44 & 0.71 \\
\hline Diabetes & $6(38 \%)$ & $5(50 \%)$ & $12(27 \%)$ & $107(31 \%)$ & 0.57 & 0.57 & 0.41 \\
\hline Creatinine & 88 [80-115] & 81 [80-89] & $92[77-131]$ & 93 [77-125] & 0.92 & 0.54 & 0.43 \\
\hline Previous MI & $7(44 \%)$ & $5(50 \%)$ & $15(33 \%)$ & $77(22 \%)$ & 0.10 & 0.05 & 0.46 \\
\hline Previous PCl & $6(38 \%)$ & $5(50 \%)$ & $8(18 \%)$ & $76(22 \%)$ & 0.53 & 0.15 & 0.11 \\
\hline $\begin{array}{l}\text { Previous cardiac } \\
\text { surgery }\end{array}$ & $1(6 \%)$ & $1(10 \%)$ & $3(7 \%)$ & $23(7 \%)$ & 0.75 & 0.29 & 0.47 \\
\hline $\begin{array}{l}\text { Previous } \\
\text { pacemaker }\end{array}$ & $5(31 \%)$ & $4(40 \%)$ & $10(22 \%)$ & $70(20 \%)$ & 0.99 & 0.95 & 0.95 \\
\hline $\begin{array}{l}\text { Current or Ex- } \\
\text { Smoker }\end{array}$ & 15 (94\%) & $9(90 \%)$ & $34(76 \%)$ & $194(56 \%)$ & 0.01 & 0.003 & 0.12 \\
\hline Atrial fibrillation & $6(38 \%)$ & $3(30 \%)$ & $14(31 \%)$ & $87(25 \%)$ & 0.38 & 0.27 & 0.64 \\
\hline $\begin{array}{l}\text { Pulmonary } \\
\text { hypertension } \\
\text { (>60mmHg) }\end{array}$ & $0(0 \%)$ & $0(0 \%)$ & 31 (69\%) & $115(33 \%)$ & $<0.001$ & 0.005 & $<0.001$ \\
\hline $\begin{array}{l}\text { Chronic lung } \\
\text { disease }\end{array}$ & 9 (56\%) & $5(50 \%)$ & $14(31 \%)$ & $82(24 \%)$ & 0.27 & 0.003 & 0.08 \\
\hline TIA/CVA & $5(31 \%)$ & $4(40 \%)$ & $6(13 \%)$ & $63(18 \%)$ & 0.42 & 0.19 & 0.11 \\
\hline $\begin{array}{l}\text { Peripheral } \\
\text { vascular disease }\end{array}$ & $13(81 \%)$ & $9(90 \%)$ & $25(56 \%)$ & $73(21 \%)$ & $<0.001$ & $<0.001$ & 0.07 \\
\hline AV peak gradient & 74 [65-78] & 74 [60-77] & 78 [65-96] & 71 [60-85] & 0.11 & 0.59 & 0.22 \\
\hline
\end{tabular}




\begin{tabular}{|l|l|l|l|l|l|l|l|}
\hline (mmHg) & & & & & & \\
\hline AV area (cm $)$ & $0.7[0.6-0.8]$ & $0.8[0.6-0.8]$ & $0.6[0.5-0.7]$ & $0.6[0.5-0.8]$ & 0.008 & 0.79 & 0.10 \\
\hline $\begin{array}{l}\text { Aortic annulus } \\
\text { (mm) }\end{array}$ & $25[24-27]$ & $24[24-25]$ & $23[21-25]$ & $24[22-25]$ & 0.26 & 0.09 & 0.16 \\
\hline LV >50\% & $12(75 \%)$ & $7(70 \%)$ & $10(22 \%)$ & $202(58 \%)$ & $<0.001$ & 0.32 & $<0.001$ \\
LV 30-49\% & $2(13 \%)$ & $1(10 \%)$ & $30(67 \%)$ & $102(29 \%)$ & & & \\
LV <30\% & $2(13 \%)$ & $2(20 \%)$ & $5(11 \%)$ & $43(12 \%)$ & & & \\
\hline
\end{tabular}

*P-values based on Person $\mathrm{chi}^{2}$ comparing medians for continuous variables and chi ${ }^{2}$ test for categorical variables. 
Table II - Procedural characteristics

\begin{tabular}{|l|l|l|l|l|l|l|l|}
\hline & $\begin{array}{l}\text { Subclavian (all) } \\
(\mathbf{n = 1 6 )}\end{array}$ & $\begin{array}{l}\text { Subclavian } \\
(\text { Lotus)(n=10) }\end{array}$ & $\begin{array}{l}\text { Transapical and } \\
\text { direct aortic } \\
(\mathbf{n = 4 5})\end{array}$ & $\begin{array}{l}\text { Femoral } \\
(\mathbf{n = 3 4 7 )}\end{array}$ & $\begin{array}{l}\text { P value femoral } \\
\text { vs transaortic/ } \\
\text { transapical* }\end{array}$ & $\begin{array}{l}\text { P value femoral } \\
\text { vs subclavian* }\end{array}$ & $\begin{array}{l}\text { P value } \\
\text { subclavian vs } \\
\text { transaortic/ } \\
\text { transapical* }\end{array}$ \\
\hline Local anaesthesia & $0(0 \%)$ & $0(0 \%)$ & $0(0 \%)$ & $210(61 \%)$ & & 0.63 \\
\hline $\begin{array}{l}\text { Post dilatation of } \\
\text { the implanted } \\
\text { valve }\end{array}$ & $3(19 \%)$ & $0(0 \%)$ & $2(13 \%)$ & $81(29 \%)$ & 0.16 & 0.40 & \\
\hline Lotus & 10 & 10 & 1 & 22 & & \\
\hline Sapien/S3/XT & 2 & 0 & 44 & 323 & & & \\
\hline $\begin{array}{l}\text { Evolute } \\
\text { R/Corevalve }\end{array}$ & 4 & 0 & 0 & 2 & & \\
\hline
\end{tabular}


Table III - Outcomes in patients undergoing TAVI

\begin{tabular}{|c|c|c|c|c|c|c|c|}
\hline & $\begin{array}{l}\text { Subclavian } \\
\text { (all) }(n=16)\end{array}$ & $\begin{array}{l}\text { Subclavian } \\
\text { (Lotus)(n= 10) }\end{array}$ & $\begin{array}{l}\text { Transapical and } \\
\text { direct aortic }(n= \\
45)\end{array}$ & $\begin{array}{l}\text { Femoral } \\
(n=347)\end{array}$ & $\begin{array}{l}\text { P value } \\
\text { femoral vs } \\
\text { transaortic/ } \\
\text { transapical* }\end{array}$ & $\begin{array}{l}\text { P value } \\
\text { femoral vs } \\
\text { subclavian* }\end{array}$ & $\begin{array}{l}\text { P value } \\
\text { subclavian } \\
\text { vs } \\
\text { transaortic/ } \\
\text { transapical* }\end{array}$ \\
\hline $\begin{array}{l}\text { Procedural } \\
\text { success }\end{array}$ & $16(100 \%)$ & $10(100 \%)$ & $44(98 \%)$ & $343(99 \%)$ & 0.55 & 0.67 & 0.55 \\
\hline In hospital death & $0(0 \%)$ & $0(0 \%)$ & $5(11 \%)$ & $14(4 \%)$ & 0.04 & 0.41 & 0.16 \\
\hline 30 day mortality & $0(0 \%)$ & $0(0 \%)$ & $5(11 \%)$ & $13(4 \%)$ & 0.03 & 0.43 & 0.16 \\
\hline $\begin{array}{l}\text { Stroke/TIA to } \\
\text { discharge }\end{array}$ & $0(0 \%)$ & $0(0 \%)$ & $2(4 \%)$ & $1(0.3 \%)$ & 0.003 & 0.83 & 0.39 \\
\hline Tamponade & $0(0 \%)$ & $0(0 \%)$ & $1(2 \%)$ & $10(3 \%)$ & 0.80 & 0.49 & 0.55 \\
\hline Periprocedural MI & $0(0 \%)$ & $0(0 \%)$ & $1(2 \%)$ & $5(1 \%)$ & 0.69 & 0.63 & 0.55 \\
\hline $\begin{array}{l}\text { AR by echo } \\
\text { (moderate or } \\
\text { more) }\end{array}$ & $0(0 \%)$ & $0(0 \%)$ & $0(0 \%)$ & $4(1 \%)$ & 0.47 & 0.67 & - \\
\hline $\begin{array}{l}\text { Emergency valve } \\
\text { in valve }\end{array}$ & $1(6 \%)$ & $0(0 \%)$ & $0(0 \%)$ & $2(0.6 \%)$ & 0.61 & 0.01 & 0.09 \\
\hline $\begin{array}{l}\text { Major access site } \\
\text { complication }\end{array}$ & $0(0 \%)$ & $0(0 \%)$ & $2(4 \%)$ & $13(4 \%)$ & 0.82 & 0.43 & 0.39 \\
\hline $\begin{array}{l}\text { Permanent } \\
\text { pacemaker during } \\
\text { or post procedure }\end{array}$ & $6(38 \%)$ & $4(40 \%)$ & $2(4 \%)$ & $22(6 \%)$ & 0.62 & $<0.001$ & 0.001 \\
\hline $\begin{array}{l}\text { New } \\
\text { haemofiltration or } \\
\text { dialysis }\end{array}$ & $0(0 \%)$ & $0(0 \%)$ & $5(11 \%)$ & $15(4 \%)$ & 0.05 & 0.40 & 0.16 \\
\hline Blood transfusion & $1(6 \%)$ & $0(0 \%)$ & $11(28 \%)$ & $28(9 \%)$ & $<0.001$ & 0.73 & $<0.001$ \\
\hline $\begin{array}{l}\text { LOS (length of } \\
\text { stay) }\end{array}$ & $3[2-3]$ & $3[2-3]$ & $7[5-11]$ & $3[2-5]$ & $<0.001$ & 0.19 & $<0.001$ \\
\hline LOS (in ICU) & 0 [0-0] & $0[0-1]$ & $2[1-4]$ & - & - & - & 0.001 \\
\hline
\end{tabular}




\section{Page 15 of 15}

Catheterization and Cardiovascular Interventions

\begin{tabular}{|l|l|l|l|l|l|l|l|}
\hline Peak CRP & $57[43-89]$ & $53[28-74]$ & $197[138-278]$ & - & - & - & $<0.001$ \\
\hline Peak CK & $\begin{array}{l}167[93- \\
202]\end{array}$ & $150[104-244]$ & $270[197-444]$ & - & - & - & 0.003 \\
\hline Chest drain & $0(0 \%)$ & $0(0 \%)$ & $30(67 \%)$ & - & - & - & $<0.001$ \\
\hline
\end{tabular}

*P-values based on Person $\mathrm{chi}^{2}$ comparing medians for continuous variables and chi ${ }^{2}$ test for categorical variables. 